\title{
Realising Rights for Homeworkers in Global Value Chains
}

\author{
Marlese von Broembsen and Jenna Harvey
}

Following the Rana Plaza building collapse in 2013 in Bangladesh, labour rights violations in global supply chains, and indeed the governance of global supply chains, have become a pressing global issue. This chapter evaluates key governance mechanisms of existing global and national supply chains from the perspective of the most vulnerable workers in the supply chains-informal home workers.

Home work is as old as capitalism itself. Since the fourteenth century, factories have subcontracted aspects of production to home workers/outworkers to transfer some of their production costs. ${ }^{1}$ The contemporary form of subcontracted work differs from previous forms, as global (as opposed to domestic) supply chains often span several continents, with different parts of a single product made in different countries. And, the procurement practices of the most powerful firms in the chain-buyers and retailers - have a more decisive impact on workers' terms and conditions of work than their relationship with the factories from which they receive their orders.

This chapter is interested in whether the emerging rights-based international law instruments for realizing decent work in global supply chains holds any promise for home workers. The academic literature refers to global value chains, global commodity chains, or global production networks. The International Labour Organization (ILO) uses the term supply chains. We will use supply chain and value chain interchangeably.

We begin the paper with a discussion on global value chains so as to contextualize home workers' terms and conditions of work within the political economy of global capitalist production. Thereafter, we discuss the United Nations Guiding Principles on Business and Human Rights and the three human rightsbased international instruments on global value chains: the ILO's Tripartite Declaration of Principles concerning Multinational Enterprises and Social Policy [hereafter the ILO's MNE Declaration], the Organization for Economic

\footnotetext{
1 James Fulcher, Capitalism: A Very Short Introduction (Oxford, 2004).

(C) MARLESE VON BROEMBSEN AND JENNA HARVEY, 2022 | DOI:10.1163/9789004499614_010 This is an open access chapter distributed under the terms of the CC BY-NC-ND 4.o license.
} 
Co-operation and Development (OECD) Guidelines for Multinational Enterprises, and the OECD Due Diligence Guidance for Responsible Supply Chains in the Garment and Footwear Sector. While only the OECD instrument on the garment and footwear sector explicitly includes home workers, we argue that home workers are covered implicitly by the other instruments. These instruments constitute soft law, meaning that they are legally non-binding. Nevertheless, recognition at the global level is often a precursor to securing recognition, and rights, at the national level. We also explore how home workers in Thailand and Bulgaria used ILo Convention No. 177 on Home Work to fight for the recognition of home workers as workers, at the domestic level.

Our argument is for a plural, overlapping governance perspective that focuses on regulatory mechanisms at local, national, regional, and global levels. Support for the participation of representative organizations of home workers is critical for these regulatory mechanisms to be effective. If home workers are excluded from law and law-making processes, it is likely that multinational enterprises (MNEs) will ban home work. Apart from its implications for home workers, other workers' rights would also be compromised by this.

\section{1 Global Value Chains and Home Workers}

A recent International Labour Organization (2017) survey of 1,454 factories from 87 countries that supply MNE s found that suppliers face intense competition to produce goods for as little as possible, and buyers exploit this competition by continually pressuring their suppliers to drop their prices. Up to $5^{2}$ per cent of suppliers that were surveyed have signed contracts to produce goods at a loss. They did so to secure future orders. Demanding unpaid overtime, keeping wages low, and outsourcing to home workers are the suppliers' primary tactics for keeping their costs low. Home workers can be exploited because they are largely invisible and seldom enjoy legal protection, as this telling statement shows: "The manager candidly admitted that since government inspectors cannot inspect private homes, it is cheaper and easier to simply outsource work to home-based workers". ${ }^{2}$

The question is, how to improve working conditions within these chains? Global value chain scholars argue that countries and firms can appropriate more value by pursuing "upgrading" strategies. Humphrey and Schmitz suggest four different ways in which firms can "upgrade": through product upgrading,

2 M. Zhou, "Pakistan's Hidden Workers: Wages and Conditions of Home-based Workers and the Informal Economy" (Geneva, 2017), available www.ilo.org, last accessed 28 May 2021. 
which involves producing a different, more complex product (and therefore being able to charge more for it); production upgrading, which involves improving the efficiency of the production process, often by improving technology (which lowers production costs); functional upgrading, which involves building the capacity and skills of workers to assume more sophisticated functions; and chain upgrading, which involves transitioning to a different industry. ${ }^{3}$ What are the implications for home workers if they, or the factory, pursue any one of these strategies?

The Donor Committee for Enterprise Development, comprising the major enterprise development funders, has published case studies showing that functional upgrading (improving home-based workers' skills) leads to higher incomes. Country-level studies, however, ${ }^{4}$ show that even when the upgrading strategies of factories are successful, the gains are often short-lived. Consequently, they are resistant to passing on their gains to workers (including home workers). The oligopolistic power of lead firms means that technocratic "upgrading" solutions are not the answer. And, given that the buyers are domiciled in industrialized countries and factories in developing countries, these global supply value chains effectively escape regulation.

In 2011, in response to this "governance gap", the UN Human Rights Council adopted the UN Guiding Principles on Business and Human Rights [hereafter UN Guiding Principles or G P s), which were drafted by UN Special Representative for Business and Human Rights John Ruggie, following global consultation. Ruggie argued that because states are unable to regulate transnational corporations, their activities resulted in human rights abuses. ${ }^{5}$ The GP s have been incorporated into the OECD Guidelines for Multinational Enterprises and the ILO'S MNE Declaration. In the next section of this chapter, we discuss these rights-based governance mechanisms, and explore whether they hold potential to improve home workers' wages and working conditions. Thereafter we compare the different instruments in terms of their strengths and weaknesses.

3 J. Humphrey and H. Schmitz, "How does insertion in global value chains affect upgrading in industrial clusters?" Regional Studies, 36:9 (2002), pp. 1017-1027.

4 Reporting on their study of thirty countries and drawing on four other studies, Milberg and Winkler (2011) state that with the exception of a study of the apparel and footwear industry, the data contest the correlation between economic and social upgrading. Ironically, as firms capture more value, the real wages and working conditions of their workers deteriorate. Beinhardt and Milberg's (2011) study of nineteen countries across four sectors concludes that there is a trade-off between employment growth and growth in wages. More jobs mean a decline in wages.

5 John Ruggie, "Guiding Principles on Business and Human Rights: Implementing the United Nations 'Protect, Respect and Remedy' Framework”, UnHR Council (2011), A/HRC/17/31:2. 


\section{International Human Rights Instruments}

\subsection{The UN Guiding Principles on Business and Human Rights}

The Guiding Principles represent the first UN endorsed corporate human rights responsibility initiative. The GPs constitute soft law, meaning they do not impose any binding legal obligations upon states or corporations. Nevertheless, they represent an important instrument as the first framework that outlines the duties of national states derived from human rights treaties, and that outline corporations' moral responsibilities. The GP s establish three pillars: states' duty to protect human rights; corporations' responsibility to respect human rights; and access to remedy. Each is discussed in turn below.

\subsection{State duty to protect human rights}

While the GPs are not legally binding, they nevertheless frame states' responsibility to protect human rights as mandatory, based on their obligations under international human rights law to individuals within their territory. The GP s also establish that states should take steps to ensure that their corporations respect human rights in other countries. The GPs recommend that states: Enforce existing laws (including labor laws) that protect human rights and require corporations to "report on their human rights impacts;" Ensure that human rights are respected in their own supply chains; and Establish complaints mechanisms to address alleged human rights violations.

\subsection{Corporate responsibility to respect human rights}

The GP s cite two international legal instruments - the Universal Declaration of Human Rights and the ILO Declaration on Fundamental Principles and Rights at Work - that provide the framework for businesses' responsibility. The GPs state that businesses have a responsibility to address "human rights impacts" which they have caused or contributed to through their own activities, but also to "prevent or mitigate" behavior by actors in their supply chains (such as suppliers or subcontractors) that violate workers' rights, even where they have not contributed to those violations. Businesses are expected to fulfill this responsibility by: Drafting a human rights policy, which should be communicated to all their stakeholders and adhered to in their business practices; Undertaking a due diligence of each supply chain to assess whether any act or omission in the production process might be contravening domestic law and/or causing human rights violations to workers; and Implementing remediation processes, including an operational-level grievance mechanism. 


\section{$2.4 \quad$ Access to remedy}

States are responsible for establishing both judicial and non-judicial grievance mechanisms as part of a "comprehensive state-based system for the remedy of business-related human rights abuse". The GP s outline a set of effectiveness criteria for non-judicial grievance mechanisms. Specifically, these should be: legitimate, accessible, predictable, equitable and transparent. They also state that remediation measures could include "an apology, restitution, rehabilitation, financial or non-financial compensation and punitive sanctions (whether criminal or administrative, such as fines), as well as the prevention of harm through, for example, injunctions or guarantees of non-repetition". Businesses are expected to establish operational-level grievance mechanisms as a first port of call for grievances that should be "accessible directly to individuals and communities who may be adversely impacted by a business enterprise".

The GPs do not explicitly refer to homeworkers. Homeworkers may, however, be covered implicitly, in terms of two provisions. First, the GP s state that a corporation's due diligence should include activities linked to its "operations, products or services by its business relationship". "Business relationship" is defined as "relationships with business partners, entities, in its value chain, and any other .... entity directly linked to its business operations, products or services," which arguably includes sub-contractors who contract to homeworkers. Second, the due diligences process should involve "meaningful consultation with potentially affected groups and other relevant stakeholders". Businesses should "seek to understand the concerns of potentially affected stakeholders by consulting them directly in a manner that takes into account language and other potential barriers to effective engagement". This consultation requirement could present an opportunity for homeworker organizations to participate in due diligence processes. A weakness is a lack of clarity as to the form that consultation should take, which undermines the requirement.

\section{3}

\section{The UN Guiding Principles on Business and Human Rights}

The Guiding Principles represent the first UN-endorsed corporate human rights responsibility initiative. The GPs constitute soft law, meaning that they do not impose any binding legal obligations upon states or corporations. Nevertheless, they represent an important instrument as the first framework that outlines the duties of national states derived from human rights treaties, and that outline the moral responsibilities of corporations. The GP s establish 
three pillars: states' duty to protect human rights; corporations' responsibility to respect human rights; and access to remedy. Each of these is discussed in turn below.

\section{States' Duty to Protect Human Rights}

While the GP s are not legally binding, they nevertheless frame states' responsibility to protect human rights as mandatory, based on their obligations under international human rights law to individuals within their territory. ${ }^{6}$ The GPs also establish that states should take steps to ensure that their corporations respect human rights in other countries. ${ }^{7}$ The GP s recommend that states: enforce existing laws (including labour laws) that protect human rights and require corporations to "report on their human rights impacts"; ensure that human rights are respected in their own supply chains; and establish complaints mechanisms to address alleged human rights violations.

The GPs cite two international legal instruments-the Universal Declaration of Human Rights and the Declaration on Fundamental Principles and Rights at Work - that provide the framework for the responsibility of businesses. The GPs state that businesses have a responsibility to address "human rights impacts" which they have caused or contributed to through their own activities, but also to "prevent or mitigate" behaviour by actors in their supply chains (such as suppliers or subcontractors) that violate workers' rights even where they have not contributed to those violations. Businesses are expected to fulfil this responsibility by: drafting a human rights policy, which should be communicated to all their stakeholders and adhered to in their business practices; undertaking due diligence of each supply chain to assess whether any act or omission in the production process might be contravening domestic law and/

6 Penelope Simons and Audrey Macklin, The Governance Gap: Extractive Industries, Human Rights and the Home State Advantage (London, 2014).

7 Indeed, one of the principal criticisms of the GP is that it does not go far enough to address the need for extra-territorial regulation. See Simons and Macklin, The Governance Gap; Rosaria Burchielli, Annie Delaney, and Maria Montesano, "Regulatory Challenges in the Australian Garment Industry: Human Rights in a Post-Ruggie Environment", Labour \& Industry: A Journal of the Social and Economic Relations of Work, 23:1 (2013), pp. 69-88. 
or causing human rights violations to workers; and implementing remedial processes, including an operational-level grievance mechanism.

\section{$6 \quad$ Access to Remedy}

States are responsible for establishing both judicial and non-judicial grievance mechanisms as part of a "comprehensive state-based system for the remedy of business-related human rights abuse". The GP s outline a set of effectiveness criteria for non-judicial grievance mechanisms. Specifically, these should be legitimate, accessible, predictable, equitable, and transparent. They also state that remedial measures could include "an apology, restitution, rehabilitation, financial or non-financial compensation and punitive sanctions (whether criminal or administrative, such as fines), as well as the prevention of harm through, for example, injunctions or guarantees of non-repetition". ${ }^{9}$ Businesses are expected to establish operational-level grievance mechanisms as a first port of call for grievances that should be "accessible directly to individuals and communities who may be adversely impacted by a business enterprise". ${ }^{10}$

The GP s do not explicitly refer to home workers. Home workers may, however, be covered implicitly, under two provisions. First, the GPs state that a corporation's due diligence should include activities linked to its "operations, products or services by its business relationship".1 "Business relationship" is defined as "relationships with business partners, entities, in its value chain, and any other ... entity directly linked to its business operations, products or services", which arguably includes subcontractors who contract to home workers. Second, the due diligence process should involve "meaningful consultation with potentially affected groups and other relevant stakeholders". ${ }^{12}$ Businesses should "seek to understand the concerns of potentially affected stakeholders by consulting them directly in a manner that takes into account language and other potential barriers to effective engagement".13 This consultation requirement presents an opportunity for home worker organizations to participate in

8 These grievance mechanisms could include: civil and criminal courts, administrative bodies, human rights institutions, national contact points, labour tribunals, mediation, "or other culturally appropriate and rights compatible processes". See Ruggie, "Guiding Principles on Business and Human Rights", p. 3 .

9 Ibid., p. 27.

$10 \quad$ Ibid., p. 31.

11 Ibid., p. 15 .

12 Ibid., p. 19.

13 Ibid., p. 20. 
due diligence processes. A weakness is the lack of clarity as to the form consultation should take, which undermines the requirement.

The OECD Guidelines for Multinational Enterprises apply to the forty-seven countries that adhere to the OECD Declaration on International Investment and Multinational Enterprises. The Guidelines represent governments addressing MNEs that are operating from or in signatory countries, and constitute "non-binding principles and standards for responsible business conduct in a global context consistent with applicable laws and internationally recognized standards". ${ }^{14}$ They cover numerous areas, among them: employment and industrial relations; the environment, bribery and extortion; consumer interests; and competition and taxation. The Guidelines were amended in May $2011^{15}$ to incorporate the UN Guiding Principles by adding a chapter on human rights and including a section in chapter II on supply chain management that applies the GPs' risk-based due diligence process. As the OECD Guidelines mirror provisions in the UN Guiding Principles, they implicitly cover home workers.

The Guidelines respond to the GPs' recommendation that states provide a non-judicial grievance mechanism ${ }^{16}$ by requiring signatory countries to establish a "national contact point" (NCP) that can adopt a range of institutional forms. NCPs are tasked with promoting and implementing the Guidelines, and reviewing complaints of corporate non-compliance by trade unions, nonprofit organizations, governments, and even members of the public. ${ }^{17}$ As of 2017 , NCP S in more than 100 countries have handled over 400 cases. $^{18}$

Although participation in the process is voluntary, MNEs engage in order to prevent reputational risk, or to avoid formal legal charges. ${ }^{19}$ Some of these

\footnotetext{
14 OECD, OECD Guidelines for Multinational Enterprises 2011 Edition (Paris, 2013), p. 3; available https://www.oecd.org/corporate/mne/, last accessed 12 December 2020.

15 The OECD Guidelines were first signed in 1976.

16 However, authors such as Simons and Macklin have pointed out that the NCPs do not necessarily meet the "effectiveness criteria" outlined in the Guiding Principles for nonjudicial grievance mechanisms (see Simons and Macklin, The Governance Gap).

17 Ibid.

18 For a full list of cases, see https://mneguidelines.oecd.org/database/, last accessed 27 May 2021.

19 Larry Backer, "Rights and Accountability in Development (Raid) v. Das Air and Global Witness v. Afrimex: Small Steps Toward an Autonomous Transnational Legal System for
} 
complaint processes have resulted in dialogue or mediation between the parties, and in some cases corporations have agreed to remedy the violation and pay compensation to affected individuals or groups. ${ }^{20}$

Assessments of the effectiveness of NCPS are mixed. Backer argues that NCP s can play an important role in changing corporate behaviour, which, over time, could have an effect as binding as hard law. ${ }^{21}$ The efficacy of NCP s, he argues, is attributable to their autonomy and their flexibility to apply domestic or international law rules in their findings, while at the same time conducting a decision-making process unconstrained by these very rules. Simons and Macklin are more critical, and argue that a lack of the required procedural standards is responsible for a lack of consistency and accountability among NCPs. ${ }^{22}$ For example, there is no requirement that NCPs should establish an appeals process, monitor the implementation of a decision, or issue a decision when parties do not reach agreement. When a dispute resolution process is initiated, there is no required time-frame for concluding it.

We believe that NCP s could be a strategic site of struggle for home workers and their allies, in particular because the OECD Due Diligence Guidance for Responsible Supply Chains in the Garment and Footwear Sector-a key sector for home workers-explicitly recognizes that home workers are legitimate workers in global value chains.

The ofcD Due Diligence Guidance for Responsible Supply Chains in the Garment and Footwear Sector [hereafter OECD Guidance] was agreed to in $2017,{ }^{23}$ after a multi-stakeholder consultative process. The OECD Guidance includes a module on "Responsible sourcing from home workers", which establishes that home workers are "an intrinsic part of the workforce entitled to receive equal treatment". ${ }^{24}$ The module includes both a framework for

the Regulation of Multinational Corporations", Melbourne Journal of International Law, 10 (2009), pp. 258-307.

20 Simons and Macklin, The Governance Gap.

21 Backer, "Rights and Accountability in Development".

22 Simons and Macklin, The Governance Gap.

23 Since the 2011 update to the Guidelines, the OECD has clarified what the due diligence process should involve and developed a due diligence guidance for five different sectors including the garment and footwear sector-which is a key sector for home workers.

24 OECD, OECD Due Diligence Guidance for Responsible Supply Chains in the Garment and Footwear Sector (Paris, 2018), p. 182. 
"preventing and mitigating human rights and labour abuses when engaging home workers", directed at a range of stakeholders, and a set of recommendations for enterprises to follow in designing their due diligence processes. The framework advocates the formalization of home workers through legal identity, recognition of their worker status, and contracts and/or authorizations that would facilitate legalization of their work. The text notes that formalization is a process, and that legalization should not involve the imposition of requirements that would be prejudicial to home workers. The framework also states that organizing home workers is a critical step towards their participation in social dialogue. Unfortunately, it does not reference ILO Recommendation 204 on Transitioning from the Informal to the Formal Economy, which provides guidelines on achieving progressive formalization with an emphasis on extending labour rights and social protection to informal workers.

Enterprises are encouraged to (i) identify potential and actual harms, and (ii) prevent or mitigate harms that are caused by the enterprise or are present in the supply chain. Under the first objective, enterprises are encouraged to identify production processes and sourcing countries where home workers are likely to be prevalent, and to assess whether suppliers in these areas have procedures in place for responsible sourcing from home workers. Enterprises should build their suppliers' capacity to implement the following measures: (i) a "pre-qualification system" for intermediaries who contract work to home workers; (ii) internal protocols for contracting work to home workers; (iii) training for intermediaries involved in contracting work to home workers; and (iv) contractual transparency requirements from intermediaries that contract work to home workers. ${ }^{25}$ Transparency requirements could include keeping records of all workers receiving orders, the details of the orders and of any social benefits provided to home workers-e.g., transporting the raw materials and finished goods.

The recommendations also include supportive measures that MNEs can take, including partnering with local initiatives that support home workers, and engaging with local and national governments to "promote the rights of home workers to access equal treatment [to other workers] under the law". ${ }^{26}$

Although the OECD Guidance represents significant progress in explicitly mentioning home workers, its potential to protect home workers is limited by its soft law status. Also, there are significant omissions in the framework and recommendations. For example, while it mentions the importance of

25 Ibid., pp. $184-85$.
26 Ibid., p. 185 . 
organizing home workers, MNEs are not encouraged to recognize existing representative organizations of home workers as legitimate partners in the due diligence process, including discussions on the form that transparency requirements and grievance procedures should take. And, a key recommendation should be that MNE s require their suppliers to mention the name of their brand in subcontracting agreements - a requirement in the Australian supply chain legislation. Home workers would then be able to identify the brand, research its commitment to decent work, and register complaints through its complaint mechanisms.

Despite these shortcomings, the OECD Guidance represents a potential mechanism for advocacy. Although the recommendations are limited and not binding, they recognize home workers as integral to supply chains and give legitimacy to their claims.

In November 1977, the ILO adopted the Tripartite Declaration of Principles concerning Multinational Enterprises and Social Policy, or the MNE Declaration. The ILO's Governing Body approved amendments to the MNE Declaration in 2000 and 2006 to reflect the changing realities of global production and new international labour standards. The MNE Declaration provides guidelines for "enhancing the positive and social labour effects of the operations and governance of multinational enterprises to achieve decent work for all". ${ }^{27}$ It is a voluntary instrument, therefore not binding, and cannot be adjudicated by any international adjudicatory body. ${ }^{28}$ Governments, multinational enterprises, and employers' and workers' organizations are simply invited "to observe the principles embodied therein". 29

After the 2016 International Labour Conference (ILC) general discussion on supply chains, the MNE Declaration was revised to incorporate the UN Guiding Principles. A human rights dimension is now included, which establishes responsibility on the part of corporations to identify, mitigate, prevent,

27 ILO, International Labour Office Geneva Tripartite Declaration of Principles Concerning Multinational Enterprises and Social Policy (Geneva, 2017), p. v.

28 If, however, a particular principle in the Declaration reflects an ILO convention that has been ratified by particular countries and the countries promulgated legislation to give effect to the ratification, then that principle would be binding in those countries and capable of adjudication and enforcement. 
and account for adverse human rights impacts in their supply chains. It establishes meaningful consultation with potentially affected groups as integral to the due diligence process. While the Declaration does not explicitly refer to home workers, such a provision covers home workers indirectly.

The MNE Declaration recommends that national tripartite constituents (governments, employers, and workers) establish national focal points ${ }^{30}$ to promote their principles, engage in capacity-building and information dissemination, and facilitate tripartite dialogue.

The Declaration does not mention home workers, but given that it is based on the UN Guiding Principles, which we argue includes home workers, the same argument can be made with respect to the Declaration. Workers

Although only the OECD Guidance on the garment and footwear sector explicitly mentions home workers, there is an argument that the other instruments could also cover home workers. The OECD instruments have the most traction because home worker organizations can report non-compliant companies to NCP s, including their failure to engage in "meaningful consultation" with them (as in the successful Vedanta case) as part of an advocacy strategy with allies.

Our analysis of these international agreements elides the contestations that underpin them, of course. The conclusions of the ILC tripartite general discussion on supply chains recognize that home workers are an ineluctable part of supply chains, which established the basis for their inclusion in the Due Diligence Guidance for Responsible Supply Chains in the Garment and Footwear Sector. This recognition was hard-won: home worker organizations participated in the discussions and the global research advocacy network, Women in Informal Employment: Globalizing and Organizing (WIEGO), ${ }^{31}$ participated in pre-conference caucuses with the International Trade Union Confederation (ITUC) and in post-conference workshops facilitated by the Global Labour Union.

Despite their soft law (non-binding) status, these instruments are significant for home workers for several reasons. First, human rights rhetoric shifts

$30 \quad$ ILO, Tripartite Declaration of Principles, Annex II, $\mathrm{lb}$.

31 Women in Informal Employment, Globalizing, and Organizing - a research advocacy network of membership-based organizations, researchers, and development practitioners. See www.wiego.org. 
public consciousness, which is often a precursor to "enforcement" through social pressure by civil society groups, called "new governance" in legal theory, and it can be used in advocacy to generate the political will necessary to enact legislation at the national level. Second, recognition at the global level is often a precursor to securing recognition, and rights, at the national level. For example, home workers in Thailand and Bulgaria have used ILo Convention No. 177 on Home Work (C177) to fight for the recognition of home workers as workers, at the domestic level.

The next sections reflect on this interplay between national and international law. We start with a discussion on $\mathrm{C}_{177}$, which is followed by a discussion of national legislation in three countries: Bulgaria, Thailand, and Australia. The aim is to remind us that both the existence of the law and its content are an outcome of political struggle, as is its enforcement. Enforcement is contingent upon strong organizations of home workers and support from civil society - most notably from trade unions, but also from non-profit organizations, development organizations, and donors.

I LO Convention No. 177 on Home Work and National Legislation to Protect Home Workers

The Self-Employed Women's Association (sEwA) of India, the world's largest trade union of informal workers, facilitated international exchange and dialogue among home worker groups in Southeast Asia and Europe in the 1980s. In the mid-199os, it spearheaded the formation of an international network, HomeNet, and a global campaign for a Convention on Home Work.

Prior to the adoption of $\mathrm{C}_{77}$ in 1996, the ILO's stance on home work was that it was exploitative, but that home workers were too disparate and isolated to be organized. ${ }^{32}$ In the absence of formal representation at the ILO, HomeNet advocated home workers' demands through formal trade union channels, and received support from the International Union of Foodworkers (IUF), the International Confederation of Free Trades Unions (ICFTU) and the International Textiles, Garments and Leather Workers Federation (ITGLWF). The principal demand of home workers was that they should enjoy the same labour rights as other waged workers. ${ }^{33}$ The Convention was agreed to in 1996.

32 Renana Jhabvala and Jane Tate, "Out of the Shadows: Home-based Workers Organize for International Recognition”, Seeds, 18 (1996).

33 Wiego, "Commemorating Twenty Years of the ILO Home Work Convention 177 (19962016)" (Cambridge, MA, 2016), available www.wiego.org, last accessed 28 May 2021. 
C177 advocates that home workers must be treated the same as other waged workers. It establishes home workers' rights to freedom of association, occupational health and safety, fair remuneration, freedom from discrimination, social security protection, access to training, minimum employment age, and maternity protection (Article 4). And it states that home workers must be included in national labour statistics. Only eleven countries have ratified the Convention.

After the Convention's ratification in 1996, organizing and network-building efforts shifted from international to regional levels, and HomeNet South East Asia (HNSEA), ${ }^{34}$ HomeNet South Asia (HNSA), ${ }^{35}$ and HomeNet Eastern Europe were formed. ${ }^{36}$ Since the adoption of $\mathrm{C}_{177}$, home workers' organizations and their allies have advocated for legislation at the domestic level. We review these efforts in Bulgaria, Thailand, and Australia below.

Legislation that protects home workers typically employs one of three approaches. The first approach expands the traditional employment and/or labour relations legislation that covers employees to include subcontracted work, including home workers. The legislation therefore creates labour rights for home workers as if they were employees. The second approach is to legislate specifically to protect home workers, as is the case in Thailand. The third approach, which Australia has adopted in the textile, garment, and footwear sectors, is to combine a "due diligence" human rights approach with a mandatory code that contains stringent enforcement mechanisms. Below, we describe each of these approaches, including the political struggle that resulted in the legislation.

\section{Bulgaria: Expanding Existing Labour Legislation}

Several countries, including Bulgaria, Chile, Brazil, Nicaragua, Uruguay, and South Africa, have amended their labour legislations to incorporate subcontracted work, including home work. We discuss Bulgaria because the

34 HomeNet South East Asia (HNSEA) has five affiliated national organizations from Cambodia, Indonesia, Laos, Thailand, and the Philippines, that represent 25,698 workers.

35 HomeNet South Asia (HNSA) has 57 affiliate organizations representing over 6oo,ooo workers from Afghanistan, Bangladesh, Bhutan, India, Maldives, Nepal, Pakistan, and Sri Lanka.

36 HomeNet Eastern Europe (HNEE) has thirteen affiliates-the largest, AHBW, has 30,00o members (from Albania, Armenia, Bulgaria, Georgia, Kazakhstan, Kyrgyzstan, Macedonia, Montenegro, Serbia, Tajikistan, Turkey, Ukraine, and Uzbekistan) (WIEGo 2017). Organizing efforts are ongoing in Africa and Latin America. 
legislation there was amended as the result of campaigning by a movement of home-based workers, and Bulgaria has ratified $\mathrm{C}_{77}$.

The Association of Home-Based Workers, Bulgaria [hereafter Association], a democratic, membership-based organization that was registered as an association in 2002, boasts 35,000 members ${ }^{37}$ drawn from twenty-two of Bulgaria's twenty-eight provinces. It is governed by a general assembly, which comprises approximately 150 elected delegates, that meets annually. It elects a national board and chairperson every five years. Each province elects a committee and coordinators who represent the province at quarterly national meetings. If the Association were to be recognized as a trade union, it would be one of the largest trade unions in Bulgaria. ${ }^{38}$

The Association and its allies, including international NGOs, campaigned for the Bulgarian government to ratify ILO Convention No. 177, which it did in July 20o9. Subsequently, in November 2010, the government signed a "National Agreement on the Regulation of Home-based Work"39 that outlined the basis on which the Labour Code would be amended. The Labour Code was amended in 2011 to cover subcontracted "dependent" workers. The Labour Code stipulates that dependent workers must have a contract and must enjoy the same entitlements as employees, including entitlements derived through collective bargaining agreements or through social security legislation. ${ }^{40}$

According to the Association, the government has neither complied with $\mathrm{C}_{177}$ (for example, there is no home work policy and home workers are not visible in the statistics) nor implemented the Labour Code because "the government holds the opinion that because [home workers in Petrich] don't have contracts they are independent units and thus fall outside of the scope of $\mathrm{C}_{177 "}{ }^{41}$ The Association was instrumental in the formation of the union of

37 For a history of АнBW, see Dave Spooner, "Challenges and Experiences in Organizing Home-Based Workers in Bulgaria”, wiEgo Organizing Brief No. 7 (2013), available www.wiego.org, last accessed 27 May 2021. Home-based workers comprise both own account workers, and waged workers. Often, the same worker is an own account worker for part of the year and a waged worker in a different season.

$3^{8}$ Spooner, "Organizing Home-Based Workers in Bulgaria".

39 Correspondence between the Association and the ILO's International Labour Standards Department that monitors compliance with conventions (on file with the author); Spooner, "Organizing Home-Based Workers in Bulgaria"; Shelley Marshall, "A Comparison of Four Experiments in Extending Labour Regulation to Non-Standard and Informal Workers", International Journal of Comparative Labour Law and Industrial Relations, 3 (2018), pp. 281-311.

40 Ibid.

41 E-mail exchange with Violeta Zlateva on 22 July 2017. 
informal workers (Unity), which was founded in May 2014 and which represents several sectors of informal workers.

HomeNet Thailand, a HomeNet South East Asia affiliate, has been at the forefront of national advocacy efforts in Thailand for the recognition and legislative protection of home workers. Its decade-long struggle resulted in the Home Workers Protection Act of 2010. Below, we discuss the political process that led to the legislation, the terms of the Act, and reflect on whether the Act has made a difference to home workers.

In 1995, Thailand experienced an economic crisis. Factories closed down or laid off workers. Many workers became informal home-based workers, and approximately 80 per cent of all work was subcontracted. HomeNet Thailand, supported by the ILO (whose Thailand representative was previously a trade unionist), began to advocate for the recognition of home workers' contributions and for their being organized. It urged that the Ministry of Labour should extend statutory labour protection to home workers and that the statutory minimum wage should apply to them. Officials argued that this was impossible, since informal workers were not recognized as workers and villagers' livelihood activities did not constitute legitimate employment.

HomeNet Thailand campaigned for a national Act that would establish home workers' labour rights and social protection, with the support of WIEgo, the ILO, HomeNet South East Asia, the Foundation for Labour and Employment Protection (FLEP) and other allies. ${ }^{42}$ They pursued the following strategies. First, they focused on increasing the visibility of home workers in the official statistics: "We have statistics, so they cannot deny their existence".43 Second, they expanded the organizing of home workers to build a democratic, membership-based organization that could be mobilized as a political constituency. Third, they conducted research to identify issues facing home workers, which they used to mobilize the home workers and engage them in legislative processes. Fourth, they drafted legislation with the participation of home

42 WIEGO, "Winning Legal Rights for Thailand's Home-based Workers", Impact Brief (2015), available www.wiego.org, last accessed 27 May 2021.

43 Meeting with ten persons who were part of FLEP and/or HomeNet Thailand, and who recounted the history of the struggle for the Act. 
workers. And fifth, they conducted a campaign that included a media strategy and a series of hearings. ${ }^{44}$

In 2010, the Thai Parliament passed the Home Workers Protection Act, which is premised on extending equal protection to home workers and factory workers. The Act is innovative in a number of respects. First, it stipulates that home workers must be given a written contract, ${ }^{45}$ and provides that where a contract gives the hirer an "undue advantage", the court has the power to order that the terms of the contract be enforced only in so far as the terms are reasonable (section 8).

Second, the Act makes it a criminal offence to pay home workers less than the statutory minimum wage. Further, payment to home workers must be made at their place of work within seven days of delivery of the finished products, and only limited deductions may be made from such payment (section 19). Third, home workers must be informed if their work is hazardous or involves toxic substances, and the hirer must provide safety equipment. If hirers contravene these provisions, they will have to pay medical, rehabilitation, or funeral expenses (section 24). Fourth, the Act stipulates that the Ministry of Labour must draft "secondary laws" or regulations for the Act to come into effect, which should be overseen by a tripartite committee comprising director-generals from several ministries, three home worker representatives, and three "hirers". At the time of writing, seventeen of the twenty-one laws had been drafted including one dealing with minimum piece-rates. Finally, section 6 of the Act provides that where a particular case by a home worker against a hirer is believed to be "for the common good", the state will appoint a legal representative to represent the home worker in the Labour Court.

Home workers may lodge complaints with the Department of Social Protection and HomeNet Thailand delivers "know-your-rights" training to its members. But no one has complained yet. Interviews with home workers suggest that fear of losing their jobs acts as a deterrent. HomeNet Thailand has put pressure on the Department for the Protection of Informal Workers within the Labour Ministry to engage in a collaborative pilot project in three provinces to "implement" the Act, which is under way.

44 The history of the Act was collected through interviews conducted by one of the authors with ten members of HomeNet Thailand who were at the forefront of the struggle, in April 2017.

45 This stipulation addresses a common complaint of home workers. Where a written contract exists, the terms are unilaterally decided and they are not given a copy. In the absence of a written contract, home workers are only given copies of work orders, which only stipulate the number of items to be produced and the rate per piece. 


\section{Australia's Supply Chain Legislation}

In Australia, home workers, who are mostly immigrants from Vietnam and Cambodia, comprise an estimated 40 per cent of the work force in the textile, clothing, and footwear industries. ${ }^{46}$ The Textile, Clothing, and Footwear Union of Australia (TCFUA) initiated a campaign to procure labour rights for home workers. It mobilized 4,0oo Australian home workers to raise awareness among the public of their work conditions; created an organization called Asian Women at Work (AWATW) and initiated the Fair Wear Campaign (which involved unions, students, community organizations, faith groups, and other civil society allies). ${ }^{47}$ The campaign resulted in a public outcry, led to senate enquiries on home work, and placed pressure on industry leaders to support the regulation of supply chains. ${ }^{48}$

Labour law in Australia is composed of legislation-the Fair Work Act of 2009-as well as collective bargaining agreements that establish minimum conditions of employment for the industry. ${ }^{49}$ The collective bargaining agreements are negotiated with multi-employer bodies, and have statutory backing as they cover the entire industry including workers and employers not party to the agreements. These collective agreements are known as federal "awards". In 1987, the Federal Clothing Trades Award (now the Textile, Clothing, Footwear, and Associated Industries Award 2010) was expanded to include home workers. ${ }^{50}$ Home workers were now entitled to the same labour rights, such as minimum wages, overtime pay, paid vacation, maternity leave, etc., as employees.

Marshall notes that firms responded by requiring home workers to register as self-employed own account workers, which enabled the firms to claim that they were contracting with independent businesses and therefore the award did not apply. In response, the Fair Wear campaign developed a voluntary code of practice-a soft law instrument that companies signed to avoid public scandal. In 2012, lobbying by the union and allies resulted in the Fair Work Act being amended to provide for a federal mandatory code that would require retailers to demand that their suppliers extend the labour rights enjoyed by employees,

46 Michael Rawling, "Cross-jurisdictional and other Implications of Mandatory Clothing Retailer Obligations", Australian Journal of Labour Law, 27:3 (2014), pp. 191-215.

47 Ibid.

48 Burchielli, Delaney, and Montesano, "Regulatory Challenges in the Australian Garment Industry",.

49 Marshall, "A Comparison of Four Experiments".

$50 \quad$ Ibid. 
to home workers. ${ }^{51}$ While the federal mandatory code is yet to be enacted, three states enacted retailers' codes-New South Wales, South Australia, and Queensland (the last of these was repealed in 2012).

The NSw and South Australian Codes are similar, and so we analyse only the former here. In New South Wales, the Ethical Clothing Trades Extended Responsibility Scheme (referred to as the NSw Code) came into effect in December 2004. The Nsw Code is a subordinate legislation, enacted by way of proclamation under the Industrial Relations (Ethical Clothing Trades) Act 2001. It is therefore a mandatory code and compliance is obligatory as a matter of law. The Nsw Code is not only applicable to the "lead firm" or "effective business controller" at the top of the chain, but also applies to lower levels of the chain, namely suppliers and contractors. This wide coverage in itself is an innovative provision. The terms "retailer", "supplier", and "contractor" are broadly defined, which makes it difficult for these parties to escape their obligations through creative corporate structuring. The Code regulates corporations incorporated in NSW, and retailers that sell clothing in NSW but subcontract production to home workers in any Australian state. It therefore regulates corporations domiciled in other jurisdictions, including international brands.

The Code applies the "due diligence" approach envisaged by the UN Guiding Principles, but it takes this a step further by requiring firms to report both to the state and to unions; non-compliance is a criminal offence.

Retailers have the following obligations under the Code. Before entering into an agreement with a supplier, the retailer must ascertain whether the supplier or any of its subcontractors will contract work to an outworker (home worker). ${ }^{52}$ Where an outworker is to be engaged, the retailer must request the supplier to provide the names and addresses of each contractor and of each outworker. ${ }^{53}$ Retailers must in turn disclose both to the government and to the Nsw branch of the Textile Clothing and Footwear Union of Australia (the Nsw Union) the names and addresses of all suppliers, and whether outworkers are engaged in production. ${ }^{54}$ Also, "where a retailer becomes aware that an outworker has been engaged on less favourable terms than the conditions described under the applicable award or other industry instrument, the retailer is obliged to report the matter to the Nsw Union or the government". 55

$5^{1} \quad$ Rawling, "Mandatory Clothing Retailer Obligations".

$5^{2} \quad$ Nsw Code, sec. 10(1).

53 Nsw Code, sec. $10(1)(b)$, read with Part B of Schedule 2 to the Nsw Code.

54 Nsw Code, sec. 12(3), read with Schedule 1.

55 Nsw Code, sec. 11. 
Section 7 of the Nsw Code stipulates that the provisions of the Code are mandatory and apply to all persons engaged in the manufacturing of clothing products in Australia, and the supply and retail sale of those products in Nsw. Violation of the Nsw Code may therefore be prosecuted by the state. We are not aware of any prosecution resulting from a breach of the Code, but according to Rawling, ${ }^{56}$ the regulator frequently deploys the threat of prosecution, and retailers comply in order to avoid prosecution and negative media exposure.

The legislation is enforced by means of different mechanisms: government inspectorates, union monitoring, and through voluntary membership of the multi-stakeholder body, Ethical Clothing Australia. Ethical Clothing Australia assists companies to map their supply chains and to establish whether their suppliers and contractors are complying (whether home workers are "receiving their legal entitlements" and accrediting compliant companies). ${ }^{57}$

\section{5}

\section{A Comparison of the Different Approaches at the National Level}

The three approaches described above are quite different from one another, and rely on different enforcement mechanisms. In the case of Bulgaria and countries such as South Africa, Chile, Brazil, Nicaragua, and Uruguay, existing labour legislation was amended to address disguised employment. Each country has a different legal mechanism by which the home worker can prove that she is an employee, which triggers employee rights. The weakness of this approach is that the legislation assumes an employer-employee relationship. This has two implications. First, if the home worker contracts directly with a factory, the legislation would help her show that she is de jure an employee of the factory and entitled to the same rights as other employees. If, however, she contracts with a contractor, subcontractor, or another home worker, she is likely only to be able to establish an employment relationship with the contractor and not with the factory (unless the contractor is a factory employee, or an agency relationship can be proved). This means that the claims for labour rights are against a supply chain actor who often enjoys as little bargaining power as the home worker herself. The Thai legislation has the same effect, in that the "hirer" is liable and the legislation does not deal with the hirer's claim against the factory. There has been no litigation that would enable us to see

$5^{6} \quad$ Rawling, "Mandatory Clothing Retailer Obligations".

57 Justine Nolan, "Business and Human Rights: The Challenge of Putting Principles into Practice and Regulating Global Supply Chains", Alternative Law Journal, 42:1 (2017), pp. 42-46; Marshall, "A Comparison of Four Experiments". 
how the courts are likely to deal with this lacuna. Second, if a home worker works for three different contractors on an intermittent basis, she may not be able to satisfy a court that any one of them is her employer.

Australia's legislation, by contrast, regulates the entire chain rather than only the "employment" relationship. The home worker can make a claim on anyone she regards as the "employer", and if that person is a contractor or subcontractor, he in turn can make a claim on the actual employer.

The three approaches differ in another important respect. In the case of the Bulgarian and Thai legislations, the burden of enforcement rests with the home workers. In Thailand, HomeNet Thailand is putting pressure on the government to enforce the legislation though campaigns targeted at factories complying voluntarily rather than because of inspection, and is loathe to litigate HomeNet Thailand. ${ }^{58}$ In Australia, by contrast, several value chain actors bear the responsibility for enforcement. Retailers, factories, suppliers, and contractors, each have transparency and disclosure obligations towards the state and towards trade unions. The state has the duty to inspect and can be a party to litigation, and trade unions participate in enforcement by reviewing the details reported by retailers and other parties, and have powers of inspection.

\section{Conclusion}

The global instruments recognize that lead firms (retailers and brand merchandisers in buyer-driven chains) exercise considerable power in their supply chains. The instruments are animated by a human rights framework that is based on the Universal Declaration of Human Rights and the ILo Declaration on Fundamental Principles and Rights at Work. They rely on several regulatory techniques, including:

- Normative commitments: MNE s should draft a human rights policy, distribute it to its stakeholders, and provide their suppliers with training

- Disclosure requirements: MNEs need to make disclosures about their own business practices and about their supply chains based on the due diligence of their supply chains. Due diligence includes consultations with "affected parties", which include home workers.

$5^{8}$ One of the authors, von Broembsen, spent two weeks in Thailand with HomeNet Thailand, from 27 March to 7 April 2020. One of the purposes of the visit was to discuss the implementation of the Home Worker Protection Act. 
- Using commercial "leverage": MNEs are expected to use their market power to insert labour rights in contracts with their suppliers, and to withdraw from contracts if their suppliers refuse to address human rights violations.

- Grievance mechanisms and remedies where "human rights violations" have taken place.

None of these corporate responsibilities is mandatory, of course. And none of the instruments challenges the procurement practices of corporations, including the pressure for lower and lower prices.

Nevertheless, these global instruments are significant. First, the language of human rights provides a universal standard of behaviour and a floor of rights that is disembedded, to borrow from Polanyi, from market rationales. And importantly, in the case of the OECD instruments, it enables civil society to engage in enforcement processes through national contact points. Second, the global and the national are overlapping: often, recognition of rights at the global level is a precursor to the recognition of rights at the national level and vice-versa. We have discussed home worker legislations in Bulgaria and Thailand as examples of recognition at the global level, in the form of $\mathrm{C}_{77}$, fuelling advocacy efforts at the national level. It works the other way around too- the Australian legislation was cited several times by the workers' group in the ILC General Discussion on Supply Chains as an example of legislation that holds lead firms to account, aspects of which could be replicated at the global level.

With the exception of Australia, national legislation has yet to make a difference to home workers. One of the reasons why the Bulgarian and Thai HomeNets are reluctant to litigate is because they fear that their factories will move to other countries. As Humphrey and Schmidt argue, ${ }^{59}$ in the case of "captive supply chains" which are labour-intensive, require little technical skill on the part of the supplier, and therefore few sunk costs on the part of retailers, retailers can, and do, easily move from one country to another. From a governance perspective, what is required are overlapping, plural governance mechanisms at local, national, regional, and global levels. Efforts at creating regional pacts-for example, countries in a region agreeing to legislate and enforce minimum living wages (see the Asia Minimum Wage Campaign) - are therefore as important as focusing efforts on international or national law.

In March 2017, France enacted a corporate duty of vigilance law, which makes supply chain due diligence mandatory for its corporations. The task for 
home worker organizations is to advocate for their explicit inclusion in such legislation. Otherwise, there is a real risk that MNEs will ban their suppliers from subcontracting to home workers. Home workers are organized, despite significant challenges. But they need (i) support in the form of donor-funding to build strong movements, advocacy campaigns, and to participate in global and national regulatory setting processes; (ii) alliances with formal trade unions; and (iii) their collective organizations to be legally recognized as trade unions.

Alliances between formal trade unions and home workers have proved critical to the adoption of Convention No. 177 and to Australia's comprehensive legislative framework. The institutional power and leverage of formal trade unions lend legitimacy to the claim of home workers that they are an inextricable part of global value chains. While unions are organized internationally along sectoral lines, informal workers (including contractors, subcontractors, and home workers) are largely excluded from collective bargaining between transnational sectoral unions and brands (resulting in global framework agreements), and from tripartite social dialogue at the national level.

The challenges for home workers simply to participate in the rule-making processes are numerous, but their participation is critical. If they are excluded from law (whether soft law at the global level or legislation at the national level), the risk is that corporations will simply ban home work. Apart from the devastating implications of this for home workers, the hard-won rights of factory workers will also be compromised. Home work will not be eradicated-it will simply go underground. Factories will still be under pressure to produce more for less, and they will continue to rely on the age-old mechanism of reducing their costs by subcontracting work. In the words of Zehra Khan, general secretary of the Home-Based Women Workers Federation from Pakistan, in her address to the International Labour Conference plenary on behalf of home worker organizations at the General Discussion on supply chains: "Failure to recognize the economic contribution of home workers as part of global supply chains will simply mean that the bottom of the supply chain remains unregulated".

\section{Acknowledgements}

The original version of this paper was commissioned by the Carr Center for Human Rights at the Harvard Kennedy School. The authors thank the Carr Center for permission to reproduce the paper in this volume. Our thanks to 
the Global Labour University and the Carr Center for Human Rights at Harvard University for providing the funds for this research, and to Firoza Mehrotra and Janhavi Dave from HomeNet South Asia, and Sunataree Saeng-ging from HomeNet Southeast Asia, for their assistance with field work. 